\title{
Social sustainability and social (Dis)trust in outgroups: Evidence from Germany and Spain using the Factorial Survey
}

Sostenibilidad social y (Des)confianza social en grupos externos: Evidencia de Alemania y España a través de la Encuesta Factorial

\author{
Edurne Bartolomé \\ Universidad de Deusto \\ edurne.bartolome@deusto.es \\ Hermann Dülmer \\ Universidad de Colonia \\ hduelmer@uni-koeln.de \\ Lluís Coromina \\ Universitat de Girona \\ 1luis.coromina@udg.edu
}

Summary: I. Introduction.-II. Theoretical framework and hypotheses. 1. Social identity, perceived threat and trust. 2. Hypotheses. - III. Methods, operationalisations and data. 1. The factorial survey. 2. Data. - IV. Empirical results. -V. Conclusions.

\begin{abstract}
In the short to medium term, ethnic diversity tends to reduce trust. This negative relationship can be explained by social identity theory and integrated threat theory. The latter theory distinguishes realistic (socio-economic) threat perceptions from symbolic (cultural) ones. Huntington ${ }^{1}$ believes that with the end of the Cold War, conflicts shifted from being primarily economic to cultural, mainly religious ones. The goal of this article is to disentangle for the first time the impact of different sources of perceived threat as well as of in-group/out-groupbased differences on trust by using a factorial survey conducted in Bilbao (Spain) and Cologne (Germany). Our main findings are that although both towns differ in religious and socio-economic composition, their citizens possess a similar level of generalised trust and perceive socio-economic threat as being much stronger than cultural threat. Weak evidence is also found for in-group/out-group-based differences in particularised trust.
\end{abstract}

Keywords: generalised trust, particularised trust, threat perception, factorial survey, social sustainability.

${ }^{1}$ Samuel P. Huntington, The Clash of Civilizations and the Remaking of the World Order (New York: Simon \& Schuster Paperback, 2003 [1996]). 
Resumen: En el corto y medio plazo, la diversidad étnica tiende a reducir la confianza. Esta relación negativa se puede explicar por la teoría de la identidad social y por la teoría integrada de la amenaza. La última teoría distingue la amenaza realista (socio-económica) de la simbólica (cultural). Huntington plantea que, con el fin de la guerra fría, los conflictos han cambiado de puramente económicos a culturales, y principalmente religiosos. El objetivo de este artículo es desenmarañar por primera vez el impacto de las diferentes fuentes de percepción de amenaza además de las diferencias de grupos internos/externos a través del uso de una encuesta factorial, que se llevó a cabo en Bilbao (España) y Colonia (Alemania). Nuestro principal hallazgo es que, aunque ambas ciudades difieren en su composición religiosa y socioeconómica, sus ciudadanos poseen un nivel similar de confianza generalizada y de percepción de amenaza socioeconómica que supera a la simbólica. Se han encontrado evidencias algo más débiles de las diferencias en la confianza particularizada hacia grupos externos.

Palabras clave: confianza generalizada, confianza particularizada, percepción de amenaza, encuesta factorial, sostenibilidad social.

\section{Introduction}

During recent decades, increasing immigration has significantly changed the ethnic composition of the populations in Western societies ${ }^{2}$. Several researchers have empirically found a negative relationship between ethnic diversity and trust in metropolitan areas ${ }^{3}$ and in ethnically diverse neighbourhoods ${ }^{4}$ in the United States. A negative relationship between diversity and social trust puts at risk some of the basic principles and values the construction of Europe is based upon, namely solidarity, and supposes an obstacle for social sustainability, based on growing levels of social trust and the creation of a European identity based on diversity and equality values. Empirical studies for the European context have shown rather mixed results for the relationship between ethnic diversity and trust ${ }^{5}$.

2 Stephen Castles, Hein de Haas, and Mark Miller, The Age of Migration. International Population Movements in the Modern World, 5th ed. (New York: Palgrave Macmillan, 2014).

3 Alberto Alesina y Eliana La Ferrara, "Who Trusts Others?", Journal of Public Economics 85, n. ${ }^{\circ} 2$ (2002): 207-34.

${ }^{4}$ Robert D. Putnam, "E Pluribus Unum: Diversity and Community in the Twenty-First Century. The 2006 Johan Skytte Prize Lecture", Scandinavian Political Studies 30, n. 2 (2007): 137-74.

5 Peter Dinsen y Kim Sønderskov, "Trust in a Time of Increasing Diversity: On the Realtionship between Ethnic Heterogeneity and Social Trust in Denmark from 1979 until Today", Scandinavian Political Studies 35, n. 4 (2012): 273-94; Marc Hooghe,, Tim Reeskens, Dietlind Stolle y Ann Trappers, "Ethnic Diversity and Generalized Trust in Europe A Cross-National Multilevel Study", Comparative Political Studies 42, n. 2 (2009): 198-223; Henrik Lolle y Lars 
However, by simultaneously analysing repeated cross-sectional survey data from the European Social Survey (2002-2010) via multilevel analysis, Ziller ${ }^{6}$ could show that "higher levels of immigration and immigration growths over time are both related to lower trust". Economic and cultural conditions moderate this relationship.

In the social sciences, generalised social trust can be distinguished from particularised social trust. Generalised trust is "the belief that most people can be trusted", while particularised trust is the "notion that we should only have faith in people like ourselves" ". To measure generalised trust, most surveys use the tried and tested standard question, "Generally speaking, would you say that most people can be trusted or that you need to be very careful in dealing with people?" 8 . Compared to the use of this general question, only a few surveys ask questions about particularised trust $^{9}$, as, for instance, about trust in people of the respondent's own race ${ }^{10}$.

Although these and similar survey questions measure trust, none of them allows an analysis of trust for actual persons with their different combinations of socio-economic and ethnic characteristics. To overcome this research gap, a factorial survey was developed. A factorial survey is an experimental design in which the researcher combines varying descriptions of persons or situations (vignettes). In contrast to typical survey questions, respondents must judge the characteristics of persons or situations not in isolation but conjointly, which comes much closer to reality ${ }^{11}$ and therefore contributes to higher reliability and validity ${ }^{12}$.

Another advantage of the factorial survey is that it allows the analysis of generalised trust as well as particularised trust. By estimating an

Torpe, "Growing Ethnic Diversity and Social Trust in European Societies. Comparative European Politics", Comparative European Politics 9, n. ${ }^{\circ} 2$ (2011): 191-216; Patrick Sturgis, Ian BruntonSmith, Sanna Read y Nick Allum, "Does Ethnic Diversity Erode Trust? Putnam's "Hunkering down" Thesis Reconsidered", British Journal of Political Science 41, n. ${ }^{\circ} 1$ (2011): 57-82.

${ }^{6}$ Conrad Ziller, "Ethnic Diversity, Economic and Cultural Contexts, and Social Trust: Cross-Sectional and Longitudianal Evdidence from European Regions, 2002-2010”, Social Forces 93, n. ${ }^{\circ} 3$ (2014): 12-34.

7 Eric M. Uslaner, The Moral Foundations of Trust (Cambridge: Cambridge University Press, 2002), 21.

${ }^{8}$ Jan Delhey, Kenneth Newton y Christian Welzel, "How General Is Trust in 'Most People'? Solving the Radius of Trust Problem", American Sociological Review 76, n. 5 (2011): 787.

9 Uslaner, The Moral Foundations...; Kenneth Newton y Sonja Zmerli, “Three Forms of Trust and Their Associates", European Political Science Review 3, n. 5 (2011): 169-200.

10 Robert D. Putnam,, "E Pluribus Unum ...”: 137-74.

11 Michael Beck y Karl-Dieter Opp, "Der Faktorielle Survey und die Messung von Normen”, Kölner Zeitschrift für Soziologie und Sozialpsychologie 52, n. ${ }^{\circ} 2$ (2001): 283-306.

12 Cheryl S. Alexander y Henry J. Becker, "The Use of Vignettes in Survey Research", Public Opinion Quarterly 42, n. 1 (1978): 93-104. 
unconditional multilevel model (empty ANOVA model) we gain a measure for generalised trust: the estimated grand mean in this case reflects the level of generalised trust, which respondents as trusters have in other people (vignette persons), independent of their specific characteristics. By proceeding in this way we also overcome a problem associated with the commonly used indicator for generalised trust, criticised ${ }^{13}$ for leaving "the circle of "most people' unspecified". As a consequence of this vagueness, the item turned out not to be predominantly associated with out-groups in all countries. Including vignette and respondent level variables in the multilevel analysis allows the statistical disentanglement of the impact of different ethnic and socio-economic characteristics of both the described fictitious vignette persons (trustees) and of the respondent characteristics (trusters) on generalised social trust (main effect model). Whereas generalised trust is an unconditional trust in other people, particularised trust is restricted to one's own in-group. The impact of such conditional trust, which is based on ties of in-group membership ${ }^{14}$, can be tested by including respective cross-level interaction terms between the vignette characteristics on the one hand and the respondent characteristics on the other hand within the multilevel model (cross-level interaction model).

The main aim of this contribution is twofold. Firstly, we empirically disentangle for the first time the impact of cultural and socio-economic threat perceptions, as caused by trustees' characteristics, on social trust. If Huntington ${ }^{15}$ is right, then it can be expected that cultural threat perceptions in the population as a whole are stronger than socio-economic ones. This especially refers to religion, which, according to Huntington, is the most central element of each culture. Secondly, we analyse the impact of ingroup/out-group-based differences on particularised trust, that is, on trust in people like ourselves ${ }^{16}$. Besides this, we also compare the level of generalised trust in both towns.

In the following, we present a conceptual framework for the basic social-psychological mechanisms which produce social trust, identify theoretically relevant determinants of trust, and derive our hypotheses. Next, we briefly introduce the methodology of factorial surveys, describe

13 Jan Delhey, Kenneth Newton y Christian Welzel, "How General Is Trust in "Most People"? Solving the Radius of Trust Problem", American Sociological Review 76, n. ${ }^{\circ} 5$ (2011): 787.

${ }^{14}$ Eric M. Uslaner y Richard S. Conley, "Civic Engagement and Particularized Trust: The Ties That Bind People to Their Ethnic Communities", American Politics Research 31, n. 4 (2003): 331-60.

${ }^{15}$ Huntington, The Clash of Civilizations...

16 UslanerThe Moral Foundations... 
operationalisations and outline the data collection. This is followed by the data analysis. Finally, we discuss the results and draw conclusions.

\section{Theoretical framework and hypotheses}

\section{Social identity, perceived threat and trust}

Due to sharply increased immigration to advanced Western societies after the $1960 \mathrm{~s}$, these societies became ethnically and culturally more diverse ${ }^{17}$. This process will most likely also continue into the future ${ }^{18}$. Although immigration, according to Putnam ${ }^{19}$, is likely to have important cultural, economic and developmental benefits in the long run, over the short to medium term, it reduces social capital. Putnam ${ }^{19}$ defines social capital as "social networks and the associated norms of reciprocity and trustworthiness", encouraging people towards the interaction and cooperation which facilitate co-ordinated actions. Commonly, trust is referred to as the most important indicator for social capital ${ }^{20}$. Theories which, together, explain the assumed negative relationship between diversity and social trust include social identity theory ${ }^{21}$ and conflict-oriented approaches, such as the integrated threat theory ${ }^{22}$. A theoretical approach which explains how threat perceptions can be mitigated is contact theory ${ }^{23}$.

Social identity theory ${ }^{24}$ is a basic approach explaining how people develop an identity as group members and how stereotypes of out-group members arise. This theory sees categorisation as a fundamental cognitive

17 Castles, de Haas y Miller, The Age of Migration...; Putnam, "E Pluribus Unum...", 137-74; Tom Van der Meer y Jochem Tolsma, "Ethnic Diversity and Its Effect on Social Cohesion", Annual Review of Sociology 40 (2014): 459-78.

18 Marc Hooghe, "Social Capital and Diversity. Generalized Trust, Social Cohesion and Regimes of Diversity”, Canadian Journal of Political Science 40, n. 3 (2007): 709-32.

19 Putnam, "E Pluribus Unum...", 137.

${ }^{20}$ Hooghe, "Social Capital and Diversity...",709-32.

${ }^{21}$ Michael Hogg y Domic Abrams, Social Identifications. A Social Psychology of Intergroup Relations and Group Processes (London: Routledge, 1988).

22 Walter G Stephan,, Oscar Ybarra y Kimberly Rios, "Intergroup Threat Theory", en Handbook of Prejudice, Stereotyping, and Discrimination, ed. por Todd D. Nelson (New York: Psychology Press, 2016), 255-78

${ }^{23}$ Gordon W. Allport, The Nature of Prejudice. (Reading, MA: Addison Wesley, 1958 [1954]); Thomas F. Pettigrew, "Intergroup Conflict Theory", Annual Review of Psychology 49 (1998): 65-85.

${ }^{24}$ Henry Tajfel y Jon Turner, "The Social Identity Theory of Intergroup Beahvior", en Psychology of Intergroup Relations, ed. por Stephen Worchel y William Austin, 2da edición (Chicago: Nell Hall, 1986):7-24; Michael Hogg y Domic Abrams, Social Identifications. A Social Psychology of Intergroup Relations and Group Processes (London: Routledge, 1988). 
process used to structure the potentially infinite variability of stimuli. As such, categorisation also produces stereotypical perceptions about all members of a social category or group. Just as people categorise other people, they also categorise themselves, which leads to an accentuation of similarities between the self and other in-group members and an accentuation of differences between the self and members of an out-group. Self-categorisation causes one to perceive oneself as having the same social identity as other members of the relevant social category. As such, selfcategorisation transforms individuals into groups.

According to social identity theory, the acquisition of knowledge is derived through social comparison. The confidence in the truth of our own view is provided by consensus among relevant people. All in all, categorisation and social comparison, together with a fundamental individual motivation for positive self-esteem, generate in-group favouritism and perceptions of an evaluative superiority of the in-group over the out-group. Out-group stereotypes are therefore based on in-group members' shared beliefs and expectations regarding the norms and behaviours of others. In this way, stereotypes also affect trust in other people, positively in the case of ingroup members and negatively in the case out-group members.

The conditions under which stereotypes lead to discrimination and the conditions under which existing stereotypes are reduced are covered by two theoretical approaches, namely conflict and contact-based approaches. Group conflict theories ${ }^{25}$ assume that negative attitudes towards out-group members are essentially rooted in perceived intergroup competition for scarce resources. Depending on the nature of the interests or scarce goods which are perceived as threatened by a group conflict, integrated threat theory ${ }^{26}$ distinguishes two types of perceived threat, namely realistic and symbolic ones. Realistic threat perceptions refer to concerns about the very existence of the in-group, to threats to the political or economic power of the in-group and to threats to the physical and material wellbeing conditions of the in-group in a specific society. Symbolic threat perceptions

${ }^{25}$ Hubert Blalock, Toward a Therory of Minority-Group Realtions (New York: John Wiley \& Sons, 1967); Jay W Jackson, "Realistic Group Conflict Theory: A Review and Evaluation of the Theoretical and Empirical Literature", The Psychological Record 43, n. 3 (1993): 395-413; Jaak Billiet, Bart Meuleman y Hans De Witte, "The Relationship between Ethnic Threat and Economic Insecurity in Times of Economic Crisis: Analysis of European Social Survey Data", Migration Studies 2, n. ${ }^{\circ} 2$ (2014): 135-61.

${ }^{26}$ Walter G. Stephan, Oscar Ybarra, Carmen Martínez Martínez y Joseph Schwarzwald, "Prejudice toward Immigrants to Spain and Israel. An Integrated Threat Theory Analysis", Journal of Cross-Cultural Psychology 29, n. 4 (1998): 559-76; Stephan, Ybarra y Rios, "Intergroup Threat Theory...". 
concern a potential challenge to the in-group's meaning system, that is, to their values, culture, religion and worldview, which they believe to be right.

The second theoretical approach is the intergroup contact theory ${ }^{27}$, where direct interpersonal contact between majority and minority group members of equal status with common goals, while supported by authority, law or custom, should lead to a reduction in intergroup prejudice. Under such optimal conditions, unfavourable stereotypes are reduced, resulting in rewarding interpersonal relationships between the members of two cooperating groups ${ }^{28}$.

According to Stephan, Ybarra, and Rios ${ }^{29}$, in practice, relations between in-groups and out-groups are far more likely to be antagonistic or competitive (conflict theory) than cooperative (contact theory). Based on conflict theory, Huntington $^{30}$ assumes that with the end of the Cold War, conflicts will be neither primarily ideological nor primarily economic. Instead, the dominating source of conflict will be cultural. Huntington ${ }^{31}$ states that culture is defined by "common objective elements, such as language, history, religion, customs, institutions, and by the subjective self-identification of people". Although language and religion are seen as the most central elements of each culture, religion is seen as more important than language. In accordance with these considerations, Lancee and Dronkers ${ }^{32}$ point to four types of diversity to be taken into account when explaining (dis-)trust in out-groups; these include economic, ethnic and religious diversity as well as language proficiency.

At this point one aspect of Uslaner's concept of particularised trust becomes important, namely its openness to extension beyond our family, friends, neighbours and colleagues to the unknown others with whom we share the same socio-economic status, ethnic origin, religion or language ${ }^{33}$. This aspect is important, since it allows us to analyse particularised trust relations in a broader way, for instance with respect to members of the same religion, which is already important in testing Huntington's thesis. Such analyses are not even possible with the item battery more recently developed for the World Values Survey 2005-07. Although the battery includes three

27 Allport, The Nature of Prejudice..., 65-85.

${ }^{28}$ Hogg y Abrams. Social Identifications..., 65-85.

29 Stephan, Ybarra y Rios, "Intergroup Threat Theory", 255-78..

${ }^{30}$ Huntington, The Clash of Civilizations....

31 Huntington, The Clash of Civilizations..., 43.

32 Bram Lancee y Japp Dronkers, "Ethnic Diversity in Neighborhoods and Individual Trust of Immigrants and Natives: A Replication of Putman (2007) in a West-European Country",en International Conference on Theoretical Perspectives on Social Cohesion and Social Capital (Brussels: Royal Flemish Academy for Science and the Arts, 2008).

${ }^{33}$ Uslaner y Conley, "Civic Engagement..."; Zmerli, Sonja y Kenneth Newton. "Winners, Losers and Three Types of Trust" en Political Trust. Why Context Matters, editado por Sonja Zmerli y Marc Hooghe, 67-94. Colchester: ECPR Press, 2011. 
items for in-group trust (trust in "your family", "your neighbourhood", "people you know personally") and three items for out-group trust ("people you meet for the first time", "people of another religion", "people of another nation" $)^{34}$, it includes no item for in-group trust, for instance in people of our own religion or our own nationality (particularised trust). This is important, since in real life, these categories sometimes overlap; a person we meet for the first time may share our nationality (in-group) but not our religion or our skin colour (out-group). The factorial survey opens the opportunity to analyse such aspects more adequately by providing more information which might be relevant to trusting others.

\section{Hypotheses}

The focus for deriving our hypotheses is the integrated threat theory, with a special interest in assumptions which can be derived from Huntington. In a first step, we will formulate a hypothesis regarding the level of generalised trust. In accordance with conflict theory, it can be argued that diversity has a negative impact on trust by strengthening the identification with the in-group at the expense of an increased conflictivity with out-groups. The two contexts to be studied differ with respect to religious heterogeneity (a symbolic threat, as measured by the Pluralism Index, i.e. 1 minus the Herfindahl-Index) and socio-economic inequality (a realistic threat, as measured by the Gini coefficient). Whereas Germany is religiously much more heterogeneous than Spain (Pluralism Index of 0.7415 and 0.3911 in 2010, respectively; own computations based on data provided by ARDA $^{35}$, socio-economic inequality is somewhat higher in Spain than in Germany (Gini coefficient of 33.7 and 29.7 in 2013, respectively ${ }^{36}$ ). However, since only two towns are included in our study, it is impossible to separate the impact of counteracting factors empirically. Instead, we refer to available empirical results. According to the European Social Survey in $2014^{37}$, the level of generalised trust in West Germany is higher than in Spain (the means for citizens on the answer scale ranging from 0 "you can't be too careful" to 10 "most people can be trusted"

${ }^{34}$ Delhey, Newton y Welzel, "How General Is Trust...”, 792; Newton, Kenneth y Sonja Zmerli. "Three Forms of Trust...”, 177.

35 ARDA, "Association of Religion Data Archives: World Religion Dataset", 2016, acceso el 14 de junio de 2016, http://www.thearda.com/Archive/Files/Downloads

36 Eurostat, "Gini Coefficient of Equivalised Disponible Income" - EU-SILC Survey, acceso el 16 de diciembre de 2016, http://appsso.eurostat.ec.europa.eu/nui/show. do?dataset=ilc_di12\&lang=en.

37 NDS, "European Social Survey (ESS7-2014 Ed.2.1)", acceso 2018, https://www. europeansocialsurvey.org/data/. 
are 5.281 and 4.815, respectively). If this relationship should also hold for Bilbao (Spain) and Cologne (West Germany), then the following relationship can be expected:

H1: The level of generalised trust should be higher in Cologne than in Bilbao.

Our next hypotheses refer to the impact of trustees' characteristics on generalised social trust (main effect model) as well as, more specifically, on in-group/out-group-based differences between trustee and truster characteristics on particularised trust (cross-level interaction model). Including two different towns in our analysis has the advantage that it offers the opportunity to test our hypotheses in two different contexts and to see whether the expected empirical patterns are similar in both towns.

According to Huntington ${ }^{38}$, culture is defined by "common objective elements, such as language, history, religion, customs, institutions, and by the subjective self-identification of people". Since religion is seen as the most central element of each culture, our hypothesis is as follows:

$\mathrm{H} 2$ : People should trust adherents of their own religion more than adherents of other religions (particularised trust, H2a). Furthermore, since most people in a town belong to the main religion of the town, people of minority religions, on average, should be less trusted than people of the majority religion $(\mathrm{H} 2)^{39}$. If religion becomes significant, the result would contribute to explaining lower levels of generalised trust.

After religion, language is seen by Huntington as the second-most important factor defining our socio-cultural identity. This leads to our next hypothesis:

H3: People should trust those with poor language skills in their mother tongue less than people fluent in their mother tongue (particularised trust, H3a). Since our analyses are restricted to respondents with the national citizenship and sufficient language skills to participate in an interview, people with poor national language skills are assumed, on average, to be less trusted than people with fluent national language skills (H3). This should contribute to lowing the level of generalised trust.

In-group out-group dynamics are also expected to relate to ethnicity, which is visible in skin colour:

H4: People should trust people of a different skin colour less than people with their own skin colour (particularised trust, H4a). Since people with black skin are a very small minority in both Germany and Spain, it is

\footnotetext{
38 Huntington, The Clash of Civilizations...

${ }^{39}$ Hypotheses for particularised trust (cross-level interaction effects) are marked by the addition of " $a$ " to the hypothesis number.
} 
expected that black people, on average, are less trusted than white people (H3), which contributes to the reduction of the level of generalised trust.

By referring to integrated threat theory, not only symbolic (ethic, cultural) threat perceptions but also realistic (socio-economic) threat perceptions are assumed to reduce social trust. A relatively low socio-economic status may be seen by people of a higher socio-economic status as a reason for distrust. The main argument for such a link is that the relative value of even a comparably low amount of cash or valuables is, ceteris paribus, higher for poorer people than for richer people. Therefore, our next hypothesis is as follows:

H5: Distrust in others should be higher, the higher the socio-economic distance between the in-group and the out-group (particularised trust, H5a). Since the socio-economic status of people with a low income is below average, it is assumed that these people, on average, are less trusted than people with a higher socio-economic status/income (H5). Therefore, high differences in the socio-economic status should also contribute to reducing the level of generalised trust.

Another characteristic assumed to be related to social trust is gender. From criminology research ${ }^{40}$, it is well established that female crime rates are much lower than male crime rates. Although this pattern is somewhat less pronounced for minor thefts such as shoplifting, the theft of services or passing bad cheques than it is for more severe crimes, the existing gender gap is quite persistent across countries and subgroups within a given country as well as over historical periods ${ }^{41}$. Besides the real gender gap, stereotypes of higher criminality amongst males also exist ${ }^{42}$. Therefore, gender is an indicator for realistic threat perceptions. This leads to our next hypothesis:

H6: Men, on average, are expected to be less trusted than women (H6). Hence, higher criminality amongst males should contribute to reducing the level of generalised trust. We will also test of whether the expected difference is weaker for men than for women (particularised trust, H6a).

Although the main focus of our study is the impact of trustees' characteristics on generalised trust as well as on in-group/out-group-based differences in particularised trust, we will also formulate some expectations concerning the impact of trusters' (respondents') characteristics on generalised social trust. Empirical research has shown that dominant groups in society show higher levels of generalised trust than marginali-

40 Darrell Steffensmeier y Emilie Allan. "Gender and Crime", Encyclopedia of Crime and Justice, 2002, ENCYCLOpedia.com, https://www.encyclopedia.com/law/legal-andpolitical-magazines/gender-and-crime; Marchbank, Jennifer y Gayle Letherby. Introduction to Gender. Social Science Perspectives, 2da edición (New York: Routledge, 2014).

${ }^{41}$ Steffensmeier y Emilie , "Gender and Crime...",

${ }^{42}$ Marchbank y Letherby, Introduction to Gender..., 315. 
sed groups ${ }^{43}$. This result is explained by the argument that marginalised groups, whether regarding ethnicity, gender or language, are objectively more likely to have experienced various forms of domination and marginalisation ${ }^{44}$; cf. also Hooghe ${ }^{45}$. A similar idea is expressed by Newton's ${ }^{46}$ "winner hypothesis", which suggests that "the trusting in society are those who are successful in social, economic and political life" 47 . Based on these considerations, we state the following hypotheses:

H7: Members of the main religion should have a higher level of generalised social trust than members of smaller denominations.

H8: People with a higher socio-economic status should show a higher level of generalised social trust than people with a lower socio-economic status.

H9: Males are assumed to have a higher level of generalised social trust than females.

Finally, we must also control for cohort effects ${ }^{48}$. A well-established theory explaining cohort effects is Inglehart's ${ }^{49}$; cf. also Zmerli and Newton $^{50}$ theory of value change. By referring to a scarcity hypothesis and a socialisation hypothesis, Inglehart ${ }^{51}$ claims that people who are socialised in a context of physical and economic insecurity are more prone to showing materialist value priorities. People socialised under conditions of high physical and economic security tend to show post-materialist value priorities for esteem, belonging and self-expression. Older cohorts who have experienced insecurity and stress in their formative years seek the predictability granted by strict rule obedience. Younger cohorts socialised under the unprecedented prosperity experienced by Western nations after World War II can more readily accept deviations from rules ${ }^{50}$ and are therefore in a better position to trust those different from them. Hence, our last hypothesis is the following:

H10: Older cohorts should tend to show lower levels of generalised social trust than younger cohorts.

43 Hooghe, "Social Capital and Diversity...", 709-32.

${ }_{44}$ Melissa Williams, Voice, Trust, and Memory. Marginalized Groups and the Failings of Liberal Representation (Princeton: Princeton University Press, 1998).

45 Hooghe, "Social Capital and Diversity...", 709-32.

46 Kenneth Newton, "Social and Political Trust",en The Oxford Handbook of Political Behavior, ed. por Russell J. Dalton y Hans-Dieter Klingemann,.(Oxford: Oxford University Press, 2007): 342-61.

${ }^{47}$ Zmerli y Newton, "Winners, Loosers and Three Types of Trust", 68.

48 Uslaner, The Moral Foundations....

49 Ronald Inglehart, Modernization and Postmodernization. Cultural, Economic and Political Change in 43 Societies (Princeton: Princeton University Press, 1997).

50 Zmerli y Newton, "Winners, Losers... a", 70.

51 Ronald Inglehart, Modernization and Postmodernization... 


\section{Methods, operationalisations and data}

\section{The factorial survey}

To test our hypotheses, we constructed a factorial survey ${ }^{52}$. A factorial survey is an experimental design in which the researcher constructs varying descriptions of fictitious persons or situations (vignettes) which will be judged by respondents under a particular aspect of theoretical interest. A vignette which describes a fictitious person includes a combination of different attributes or characteristics, for instance a female Catholic unemployed salesperson. Each of these attributes belongs to a different factor or dimension (gender, religion, employment).$^{53}$

To test our hypotheses, we created a fictitious situation where a person left their unlocked bag in a train compartment in order to go to the toilet. Before the person left the compartment, only one other person was present. In each vignette, this other person is described as 35 years old, single and not having national citizenship. These three characteristics were not of substantial interest to our study but were necessary for the sufficient specification of the hypothetic situation. The task of the respondents was to judge the likelihood of the property in the bag being stolen during the first person's absence. Figure 1 includes an example vignette and the introduction to the factorial survey, for illustrative purposes.

52 Peter H. Rossi y Andy B. Anderson, "The Factorial Survey Approach: An Introduction", en Measuring Social Judgments. The Factorial Survey Approach, ed. por Peter H. Rossi y Steven L. Nock,. (Beverly Hills, CA: Sage, 1982): 15-67; Guillermina Jasso, "Factorial Survey Methods for Studying Beliefs and Judgments", Sociological Methods \& Research 34, n. 3 (2006): 334-423; Katrin Auspurg y Thomas Hinz, Factorial Survey Experiments, Paper Series on Quantitative Applications in Social Sciences (Sage. Newbury Park, 2006).

${ }^{53}$ The central idea of a factorial survey involves transferring the basic principles of the factorial design (multivariate experimental design) into a sample survey (Rossi, Peter H. y Andy B. Anderson. "The Factorial Survey Approach: An Introduction". En Measuring Social Judgments. The Factorial Survey Approach, editado por Peter H. Rossi y Steven L. Nock, 15-67. Beverly Hills, CA: Sage, 1982). In this way, the factorial survey increases both internal validity (uncovering causal relationships) and external validity (generalisability to the broader/general population). As an experimental design, even without having a representative survey, the factorial survey allows general conclusions about causal mechanisms (Auspurg, Katrin y Thomas Hinz. Factorial Survey Experiments. Paper Series on Quantitative Applications in Social Sciences. Sage. Newbury Park, 2006). 


\section{Figure 1}

\section{Introduction and Example Vignette (Translated Spanish Version)}

On the following pages we will present you 20 similar situations where a person left his or her unlocked bag in a train compartment in order to go to the toilet. In the bag are each time his/her wallet, with about 100 Euros inside, and his/her mobile.

Before the person left the train compartment, there was only one other person there. This other person is each time 35 years old, single, has no Spanish citizenship, but differs with respect to his/her further characteristics from situation to situation. We would like to ask you to mark for each of the 20 situations how likely you think it is that the property of the person has been stolen when he/she was on the toilet. In order to answer the questions please use the following answer scale:

It is ...

\begin{tabular}{c}
$\begin{array}{c}\text { absolutely sure } \\
\text { that it has not } \\
\text { been stolen }\end{array}$ \\
\cline { 2 - 2 }
\end{tabular}

V1 Ms J. is on a train that is arriving at the next station. When she is leaving the toilet she remembers that she has left her unlocked bag in the train compartment. In the bag are her wallet, with about 100 Euros inside, and her mobile.

Before she left the train compartment, there was only one other person there, 35 years old, single, without Spanish citizenship and with the following further characteristics:

Gender:

Skin colour:

Knowledge of Spanish:

Religion:

Employment: female

white

speaks broken Spanish

Muslim

manager of a medium sized company

In your opinion, how likely is it that the property of Ms J. has been stolen during her absence by the described person? It is ...

\begin{tabular}{c}
$\begin{array}{c}\text { absolutely sure } \\
\text { that it has not } \\
\text { been stolen }\end{array}$ \\
\cline { 2 - 2 }
\end{tabular}

Note: The abbreviation of the name of the fictitious vignette person was on each vignette a different one. 
In addition to these constants, five dimensions with varying characteristics were included in our factorial survey: gender, skin colour, knowledge of the national language, religion and employment. Table 1 gives an overview of the five vignette dimensions, their levels and the coding.

\section{Table 1}

Vignette Dimensions and Levels

\begin{tabular}{lll}
\hline $\begin{array}{l}\text { Dimension (variables) describing } \\
\text { the fictitious vignette person: }\end{array}$ & $\begin{array}{l}\text { Levels (values) for the dimensions } \\
\text { (personal characteristics): }\end{array}$ & Coding: \\
\hline Gender: & - female & 0 \\
& - male & 1 \\
\hline Skin color: & - white & 0 \\
& - black & 1 \\
\hline Knowledge of German/ & - speaks fluent German/Spanish & 0 \\
Spanish: & - speaks broken German/Spanish & 1 \\
\hline Religion: & - none & Dummy-coding \\
& - Protestant & with "none" as \\
& - Catholic & \\
& - Orthodorence \\
& - Muslim & \\
\hline Employment: & - Manager of a medium sized & 0 \\
& company & 1 \\
\hline
\end{tabular}

For four dimensions, each with two levels, as well as one dimension with five levels, the completely crossed vignette universe consists of $2 \times 2 \times 2 \times 2 \times 5=80$ combinations of vignette characteristics. Since 80 vignettes could not be judged by each individual respondent, a reduced design with a smaller set size (vignette sample size per respondent) was used instead. To construct such a reduced design, a simple D-efficient design ${ }^{54}$ was generated in a first step by using the SAS computer program. D-efficiency is a measure of the goodness of a design relative to a balanced orthogonal design, that is, a design where the chosen levels appear with equal frequency and where variables of different dimensions are uncorrelated for

${ }^{54}$ Warren F. Kuhfeld, "Experimental Design: Efficiency, Coding, and Choice Designs" en Marketing Research Methods in SAS. Experimental Design, Choice, Conjoint, and Graphical Techniques, ed. por Warren F. Kuhfeld,. (Cary, NC: SAS-Institute TS-722, 2010), 53-241. 
each vignette dimension ${ }^{55}$. A D-efficiency of 100 indicates that a design which includes only qualitative variables is both balanced and orthogonal. For our study, it was possible to generate a D-efficient design with a D-efficiency of 100 for a set size of 20 vignettes per respondent. Since the vignette variables turned out to be already correlated with two-way interaction terms, 15 further D-efficient designs of the same D-efficiency were constructed by permuting the levels of interaction terms of the first design. Combing these $16 \mathrm{D}$-efficient designs produces a confounded D-efficient $\operatorname{design}^{56}$ with a D-efficiency of 100 ; hence, all vignette variables and their interaction terms are balanced as well as mutually orthogonal. Hence, the confounded D-efficient design perfectly covers the central features of the completely crossed vignette universe. After the $16 \mathrm{D}$-efficient designs were produced, we randomised the order of the vignettes. Each survey participant was randomly assigned to one of the 16 versions of the questionnaire.

\section{Data}

The fieldwork for the factorial survey was conducted in spring 2014. In Bilbao, the interviews were carried out face-to-face and in Cologne, via an online survey. To select the participants, a combined representative quota was applied to age and gender. The adult population in both towns was targeted. However, as an online survey was conducted in Cologne, only respondents born after 1947 were interviewed. A total of 304 interviews were successfully conducted in each town. In Bilbao, 14 respondents without national citizenship were excluded from analyses, and in Cologne, 10 were excluded.

For our empirical analyses, the answer scale for the factorial survey was reversed; a high value (code 10) now indicates a high level of trust. At the respondent level, gender, religion, cohort and highest level of education are included in our analyses. These predictor variables are all 0-1 dummy coded. The reference group for gender are females, the reference group for Catholics and Protestants are people without religion. Respondents from other religions were excluded (the only Protestant of Bilbao who participated in the survey was also excluded). The year 1947 was chosen as a starting point to distinguish three cohorts, namely those born in or before 1947, those born between 1948 and 1970 and those born in 1971 or later

55 Warren F. Kuhfeld, Randall D. Tobias y Mark Garratt, "Efficient Experimental Design with Marketing Research Applications". Journal of Marketing Research 31, n. ${ }^{\circ} 4$ (1994): 545-57.

${ }^{56}$ Hermann Dülmer, "The Factorial Survey: Design Selection and Its Impact on Reliability and Internal Validity", Sociological Methods \& Research 45, n. 2 (2016): 304-47. 
(reference group). The dummy variables for education (indicator for a respondent's socio-economic status) distinguish three levels, namely elementary or less than elementary education (reference group), secondary education and tertiary education. Due to the exclusions for religion and a few missing values on religion and education, the reduced sample size includes 273 respondents for Bilbao and 280 for Cologne. After also excluding respondents who judged all vignettes equally (constant answer behaviour), the net sample size was reduced further to 236 respondents for Bilbao and 213 respondents for Cologne.

Since every respondent to our factorial survey judged more than one vignette, the resulting data structure is a hierarchical one. For analysing such data, multilevel regression analysis ${ }^{57}$ is recommended. All multilevel models presented in this article have been estimated with HLM 7.

\section{Empirical results}

To see whether constant answer behaviour affects the level of generalised trust, we compared a multilevel model which includes respondents with constant answer behaviour with a model where these respondents are excluded (Table 2, Models $1 \mathrm{a}$ and 1b). By including a dummy variable for the town where the interviews were conducted at the respondent level ( 0 for Bilbao; 1 for Cologne), we also tested whether the level of generalised trust significantly differs between the two towns.

\section{Table 2}

Level of Generalised Trust (Multilevel Analysis)

\begin{tabular}{|c|c|c|c|c|}
\hline Constant Answers Excluded & \multicolumn{2}{|c|}{ Model 1a } & \multicolumn{2}{|c|}{$\begin{array}{c}\text { Model 2a } \\
\text { (Oldest Cohort for Bilbao Excluded) }\end{array}$} \\
\hline Level 1: & \multirow{2}{*}{\multicolumn{2}{|c|}{$\begin{array}{l}\text { 8,979 Vignettes a) } \\
\text { 449 Respondents }\end{array}$}} & \multirow{2}{*}{\multicolumn{2}{|c|}{$\begin{array}{l}\text { 7,639 Vignettes a) } \\
382 \text { Respondents }\end{array}$}} \\
\hline \multirow[t]{2}{*}{ Level 2: } & & & & \\
\hline & $\mathrm{b}$ & $\mathrm{t}$ & $\mathrm{b}$ & $\mathrm{t}$ \\
\hline Intercept Level 1 & & & & \\
\hline Intercept Level 2 & 5.547 & $40.973 * *$ & 5.861 & $37.726 * *$ \\
\hline $\begin{array}{l}\text { Bilbao/Cologne } \\
(\text { Cologne = 1) }\end{array}$ & .616 & $3.574 * *$ & .303 & 1.606 \\
\hline
\end{tabular}

57 Tom A.B. Snijders y Roel J. Bosker, "Modeled Variance in Two-Level Models". Sociological Methods \& Research 22, n. ${ }^{\circ} 3$ (1994): 342-63. 


\begin{tabular}{|c|c|c|c|c|}
\hline Constant Answers Included & \multicolumn{2}{|c|}{ Model 1b } & \multicolumn{2}{|c|}{$\begin{array}{c}\text { Model 2b } \\
\text { (Oldest Cohort for Bilbao Excluded }\end{array}$} \\
\hline Level 1: & \multirow{2}{*}{\multicolumn{2}{|c|}{$\begin{array}{l}11,059 \text { Vignettes a) } \\
553 \text { Respondents }\end{array}$}} & \multirow{2}{*}{\multicolumn{2}{|c|}{$\begin{array}{l}\text { 9,819 Vignettes a) } \\
\text { 491 Respondents }\end{array}$}} \\
\hline \multirow[t]{2}{*}{ Level 2: } & & & & \\
\hline & $\mathrm{b}$ & $\mathrm{t}$ & $\mathrm{b}$ & $\mathrm{t}$ \\
\hline Intercept Level 1 & & & & \\
\hline Intercept Level 2 & 5.601 & $41.076^{* *}$ & 5.907 & $38.962 * *$ \\
\hline $\begin{array}{l}\text { Bilbao/Cologne } \\
(\text { Cologne = 1) }\end{array}$ & .534 & $3.071 * *$ & .228 & 1.227 \\
\hline
\end{tabular}

Note: $* \mathrm{p} \leq 0,05 ; * * \mathrm{p} \leq 0.01$; Restricted Maximum Likelihood with Robust Standard Errors; a) In Bilbao one respondent only rated 19 instead of 20 vignettes.

Our empirical results show that by excluding the respondents with constant answer behaviour, on the 11-point scale, the level of generalised trust decreases by 0.054 units from 5.601 to 5.547 for Bilbao, while it increases by 0.028 units from $6.135(=5.601+0.534)$ to $6.163(=5.547+$ $0.616)$ for Cologne. Hence, excluding the respondents with constant answer behaviour did not substantively change the results. However, the level of generalised trust for both models is more than 0.5 scale points higher in Cologne than in Bilbao (Model 1a: $b=0.616, p<0.01$, Model 1b: $b=0.534$, $\mathrm{p}<0.01$ ).

To test whether this difference is caused by the fact that no respondents born in or before 1947 were included in the Cologne survey, the oldest cohort was also excluded from the Bilbao survey (Models $2 \mathrm{a}$ and 2b). The results show that by excluding the oldest cohort, the level of generalised trust increased for Bilbao by approximately 0.3 scale points. Consequently, the difference in the level of generalised trust between Bilbao and Cologne becomes insignificant $(b=0.303$, $p$ $>0.05$ and $b=0.228, p>0.05$, respectively). Therefore, the significant difference in Models 1a and 1b can be traced back to the lower level of generalised trust in the oldest cohort from Bilbao, which, in a first step, confirms H10. However, it does not confirm our hypothesis H1, according to which the level of generalised trust should be significantly higher in Cologne than in Bilbao.

In the next step, separate main effect multilevel models were estimated for Bilbao and Cologne (Table 3). To more easily distinguish vignette-level predictors from respondent-level predictors, the latter are indented slightly to the right in the table. 
Table 3

Multilevel Analysis of Level of Trust: Main Effect Model

\begin{tabular}{|c|c|c|c|c|}
\hline & \multicolumn{2}{|c|}{ Bilbao } & \multicolumn{2}{|c|}{ Cologne } \\
\hline $\mathrm{R}^{2}$ Vignette Level & \multicolumn{2}{|c|}{$9.32 \%$} & \multicolumn{2}{|c|}{$12.38 \%$} \\
\hline $\mathrm{R}^{2}$ Respondent Level & \multicolumn{2}{|c|}{$8.48 \%$} & \multicolumn{2}{|c|}{$0.00 \%$} \\
\hline \multirow{3}{*}{$\begin{array}{l}\text { Level 1: } \\
\text { Level 2: }\end{array}$} & \multirow{2}{*}{\multicolumn{2}{|c|}{$\begin{array}{l}\text { 4,719 Vignettes } \\
\text { 236 Respondents }\end{array}$}} & \multirow{2}{*}{\multicolumn{2}{|c|}{$\begin{array}{l}\text { 4,260 Vignettes } \\
213 \text { Respondents }\end{array}$}} \\
\hline & & & & \\
\hline & $\mathrm{b}$ & $\mathrm{t}$ & $\mathrm{b}$ & $\mathrm{t}$ \\
\hline \multicolumn{5}{|l|}{ Intercept Level 1} \\
\hline Intercept Level 2 & 5.542 & $13.031 * *$ & 6.870 & $18.773 * *$ \\
\hline Male & .599 & $2.252 *$ & -.191 & -.921 \\
\hline No Religion (Ref.) & - & - & - & - \\
\hline Protestant & & & .120 & .471 \\
\hline Catholic & -.249 & -.733 & .399 & 1.542 \\
\hline Education: & - & - & - & - \\
\hline \multicolumn{5}{|l|}{ Elementary (Ref.) } \\
\hline Education: Secondary & .720 & $2.257 *$ & -.070 & -.241 \\
\hline Education: Tertiary & .548 & $1.894 *$ & -.087 & -.264 \\
\hline Born 1971-96 (Ref.) & - & - & - & - \\
\hline Born 1948-70 & .394 & 1.255 & .307 & 1.491 \\
\hline Born 1922-47 & -.360 & -1.019 & & \\
\hline Male & -.101 & $-2.942 * *$ & -.055 & $-1.782 *$ \\
\hline Color of Skin (1=black) & -.095 & $-2.850 * *$ & .005 & .118 \\
\hline Language Skills (1=low) & -.080 & $-2.746 * *$ & -.328 & $-7.245^{* *}$ \\
\hline No Religion (Reference) & - & - & - & - \\
\hline Protestant & -.002 & -.044 & .123 & $2.631 * *$ \\
\hline Catholic & .140 & $2.600 * *$ & .144 & $3.446 * *$ \\
\hline Orthodox & -.090 & $-1.968^{*}$ & .114 & $2.227 *$ \\
\hline Muslim & -.316 & $-6.255^{* *}$ & -.075 & -1.026 \\
\hline Unemployed & -.777 & $-8.982 * *$ & -1.454 & $-15.316^{* *}$ \\
\hline
\end{tabular}

Notes: $* \mathrm{p} \leq 0,05 ; * * \mathrm{p} \leq 0.01$ (hypotheses are tested one-tailed); Restricted Maximum Likelihood with Robust Standard Errors; The pseudo $\mathrm{R}^{2}$ is calculated according to the simplified formula of Snijders and Bosker ${ }^{58}$.

1) No Protestants in the sample from Bilbao, no people born between 1922 and 1947 in the sample from Cologne.

2) One respondent of Bilbao did not rate one vignette.

3) For Cologne, the slopes for the vignette characteristics "Protestant" and "Catholic" turned out to be insignificant and have been fixed for this reason. The intercept and all other slopes were estimated with a significant random component.

58 Tom A.B. Snijders y Roel J. Bosker. "Modeled Variance in Two-Level Models". Sociological Methods \& Research 22, n. ${ }^{\circ} 3$ (1994): 342-63. 
Among the various vignette characteristics, the socio-economic status of the vignette person has by far the biggest impact on the level of generalised trust. An unemployed person is significantly less trusted than the manager of a medium-sized company ( $b=-0.777$ for Bilbao, $b=-1.454$ for Cologne). This result confirms that poorer people are perceived as less trustworthy than wealthier ones (H5). In Bilbao as a Catholic town, Catholics are significantly more trusted than those without a religion $(b=0.140)$. No significant difference exists between people without a religion and Protestants $(b=-0.002)$. Orthodox and Muslim people are least trusted, though the b-coefficient for Muslims is much bigger than the b-coefficient for the Orthodox ( $b=-0.090$ and -0.316 , respectively). Cologne is a historically Catholic town in a mixed Protestant-Catholic country ${ }^{59}$. People from all three Christian religions (Catholic, Protestant and Orthodox) are significantly more trusted than people without a religion, whereby the b-coefficients for all three religions are very similar (between 0.144 for Catholics and 0.114 for Orthodox). Furthermore, Muslims are not significantly less trusted than vignette persons without a religion $(b=-0.075)$. These results partially confirm the symbolic threat theory $(\mathrm{H} 2)$; in a region where Catholics make up the overwhelming majority, Catholics are, on average, most trusted. The more dissimilar the other religions are (in this case, Muslims compared to Christians), the less they are trusted. However, contact theory is also partially confirmed in our analyses; in a more heterogeneous environment like Cologne, trust is generalised to other religions which are perceived as quite similar to the main religion. However, trust is not generalised in the same way to less similar religions (Islam), which again corroborates to a certain degree the symbolic threat theory. People without a religion are significantly less trusted than Catholics in Bilbao; they are also significantly less trusted than Catholics, Protestants and Orthodox in Cologne.

Huntington ${ }^{60}$ points out that although culture is mainly defined by religion, language also constitutes a central element of any culture. People with poor national language skills are less adapted to the host culture and therefore should also be significantly less trusted than people who speak the national language fluently (H3). For Bilbao, this hypothesis is corroborated; here, language skills indeed play a less important role than religion

59 Estimated percentages of religions in Cologne data: Forsa-Bus 2012-2014, sample of 3,883 German-speaking people from Cologne, aged 14 and older): Catholics: $40.1 \%$, Protestants: $23.3 \%$, other Christians: $1.5 \%$, other non-Christian religions (mainly Muslim with Turkish roots): 3.6\%, no religion: 31.4\%; Forsa-Bus. 2014. "2014, 2013, 2012. GESIS Data Archive, Cologne. ZA5996, ZA5927, ZA5927. Data File Version 1.0.0”. https://doi. org/10.4232/1.12349, 10.4232/1.12174, 10.4232/1.11592.

${ }^{60}$ Huntington The Clash of Civilizations... 
( $b=-0.080$ for language skills vs. -0.456 as the maximal difference between two religions, i.e. between Catholics and Muslims). However, in Cologne, contrary to Huntington's theory, language has a bigger impact on trust than religion $(b=-0.328$ for language skills vs. -0.219 as the maximal difference between two religions, i.e. between Catholics and Muslims). Belonging to a specific ethnic minority (black skin, H4) is a further determinant of trust in Bilbao but not in Cologne $(b=0.095, p<0.01$ vs. $\mathrm{b}=0.005, \mathrm{p}>0.05)$. In accordance with our expectations (H6), males are significantly less trusted than females in both Bilbao and Cologne $(b=-0.101$ vs. $b=-0.055)$. The vignette characteristics together explain 9.32 per cent of answer behaviour in Bilbao and 12.38 per cent in Cologne.

So far, the socio-economic characteristics of the vignette persons provided a much more powerful explanation than the cultural ones. However, trust should not depend only on the characteristics of the person who must be trusted but also on the characteristics of the person who must trust. The impact of the respondent's gender (H9), religion (H7), education (H8) and cohort (H10) on generalised trust are displayed in the upper part of Table 3. The empirical results do not confirm that any of these characteristics have a significant influence on trust in Cologne. In Bilbao, however, males show a significantly higher level of trust than females $(b=0.599)$. Also, people with a secondary or tertiary level of education show a significantly higher level of trust than people with an elementary level of education ( $b=0.720$ and $b=0.548$, respectively). This result confirms that people with the lowest level of education also display the lowest level of trust (H8).

Although the two oldest cohorts do not differ significantly from the youngest cohort, the results also show that the middle cohort has a somewhat higher level of trust, whereas the oldest cohort has a somewhat lower level of trust than the youngest cohort. The difference between the middle and oldest cohorts is significant $(b=-0.754, p<0.05$, separately tested by changing the reference group). So empirically, we find a curvilinear pattern; the cohort born between 1948 and 1970 has the highest level of trust, the oldest cohort has the lowest level of trust, and the youngest cohort born in or after 1971 is in-between. Hence, hypothesis H10 is confirmed with respect to the oldest cohort.

In a final step, we test our hypotheses concerning particularised trust by including in our multilevel model cross-level interaction terms between ingroup characteristics of respondents as trusters and corresponding in-group characteristics of described vignette person as trustees. The results of the models for Bilbao and Cologne can be found in Table 4. 
Table 4

Multilevel Analysis of Level of Trust: Cross-Level Interaction Model

\begin{tabular}{|c|c|c|c|c|}
\hline & \multicolumn{2}{|c|}{ Bilbao } & \multicolumn{2}{|c|}{ Cologne } \\
\hline $\mathrm{R}^{2}$ Vignette Level & \multicolumn{2}{|c|}{$9.36 \%$} & \multicolumn{2}{|c|}{$12.70 \%$} \\
\hline $\mathrm{R}^{2}$ Respondent Level & \multicolumn{2}{|c|}{$8.48 \%$} & \multicolumn{2}{|c|}{$0.00 \%$} \\
\hline \multirow{3}{*}{$\begin{array}{l}\text { Level 1: } \\
\text { Level 2: }\end{array}$} & \multirow{2}{*}{\multicolumn{2}{|c|}{$\begin{array}{l}\text { 4,719 Vignettes } \\
\text { 236 Respondents }\end{array}$}} & \multirow{2}{*}{\multicolumn{2}{|c|}{$\begin{array}{l}\text { 4,260 Vignettes } \\
\text { 213 Respondents }\end{array}$}} \\
\hline & & & & \\
\hline & $\mathrm{b}$ & $\mathrm{t}$ & $\mathrm{b}$ & $\mathrm{t}$ \\
\hline \multicolumn{5}{|l|}{ Intercept Level 1} \\
\hline Intercept Level 2 & 5.548 & $12.819 * *$ & 6.632 & $16.797 * *$ \\
\hline Male & .624 & $2.294 *$ & -.225 & -1.063 \\
\hline No Religion (Ref.) & - & - & - & - \\
\hline Protestant & & & .102 & .402 \\
\hline Catholic & -.249 & -.721 & .381 & 1.479 \\
\hline $\begin{array}{l}\text { Education Elementary } \\
\text { (Ref.) }\end{array}$ & - & - & - & - \\
\hline Education Secondary & .620 & 1.803 & .325 & .970 \\
\hline Education Tertiary & .582 & 1.880 & .071 & .184 \\
\hline Born 1971-96 (Ref.) & - & - & - & - \\
\hline Born 1948-70 & .394 & 1.255 & .306 & 1.489 \\
\hline Born 1922-47 & -.361 & -1.019 & & \\
\hline Male & -.086 & $-2.196^{*}$ & -.091 & -1.814 \\
\hline Male & -.033 & -.486 & .054 & .872 \\
\hline Color of Skin (1=black) & -.095 & $-2.850 * *$ & .005 & .118 \\
\hline Language Skills (1=low) & -.080 & $-2.746^{* *}$ & -.328 & $-7.245 * *$ \\
\hline No Religion (Ref.) & - & - & - & - \\
\hline Protestant & -.002 & -.044 & .093 & 1.817 \\
\hline Protestant & & & .096 & 1.122 \\
\hline Catholic & .139 & 1.728 & .111 & $2.149 *$ \\
\hline Catholic & .001 & .007 & .093 & 1.261 \\
\hline Orthodox & -.090 & $-1.968 *$ & .114 & $2.227 *$ \\
\hline Muslim & -.316 & $-6.255^{* *}$ & -.075 & -1.026 \\
\hline Unemployed & -.810 & $-6.370 * *$ & -1.051 & $-6.045^{* *}$ \\
\hline Secondary Education & .177 & .787 & -.583 & $-2.748 * *$ \\
\hline Tertiary Education & -.059 & -.336 & -.233 & -.881 \\
\hline
\end{tabular}

Notes: $* \mathrm{p} \leq 0,05 ; * * \mathrm{p} \leq 0,01$ (tested one-tailed)

1) For Cologne, only the slopes for the vignette characteristics "Protestant" and "Catholic" turned out to be insignificant and have been fixed for this reason. The intercept and all other slopes were estimated with a significant random component.

For further notes, cf. Table 3 
The cross-level interaction effects between Catholics as trusters and Catholic vignette persons as trustees fail to become significant (Bilbao: $b=0.001, p>0.05$, Cologne $b=0.093, p>0.05)$. The same applies to the cross-level interaction effects between Protestant respondents and Protestant vignette persons in Cologne $(b=0.096, p>0.05)$. These results show that perceived in-group/out-group antagonisms regarding religion are too weak to strengthen in-group favouritism to the degree that the religious in-group is significantly more trusted than religious outgroups (particularised trust, $\mathrm{H} 2 \mathrm{a}$ ). Instead, trust in certain minority religions in both towns is lower in general than trust in people who belong to a majority religion (main effect model). It must be mentioned, however, that a cross-level interaction effect between Muslim respondents and Muslim vignette persons could not be tested in our study (only eight Muslims participated in the survey). Therefore, our study cannot address the question of whether particularised trust has a significant impact only amongst small minority groups.

For Cologne, one result is worth examining more closely: Protestants, Catholics and Orthodox are trusted almost equally $\left(\right.$ Table 3) ${ }^{61}$. Furthermore, neither Catholics nor Protestants are more trusted by the members of the respective religion than by people of other religions or by persons without a religion (Table 4). This pattern raises the question of whether being a member of one of these Christian denominations is more important for particularised trust than being a member of a specific religion. From their teachings, the Catholic and the Orthodox Churches are closer to each other than to the Lutheran Church, which is the main Protestant Church in Germany. There have been a number of attempts aiming towards ecumenical cooperation over a long period of time to improve the relationship between the Catholic and the Orthodox Churches ${ }^{62}$. The same also applies to the Catholic and the Lutheran Churches ${ }^{63}$. Hence, it might be that differences between these three denominations are perceived as less important than

${ }^{61}$ The differences between these three denominations turned out to be insignificant for multilevel models with Protestants and Catholics respectively as reference group.

${ }^{62}$ Apostolic Delegation. "Pilgrimage to the Holy Land on the Occasion of the 50th Anniversary of the Meeting Between Pope Paul VI and Patriarch Athenagoras in Jerusalem (24-26 May 2014): Common Declaration of Pope Francis and the Ecumenical Patriarch Bartholomew", acceso el 22 de julio de 2016, https://w2.vatican.va/content/francesco/ en/speeches/2014/may/documents/papa-francesco_20140525_terra-santa-dichiarazionecongiunta.html.

${ }^{63}$ Michael W. Chapman, "Pope Francis to Join Ecumenical Celebration of Protestant Reformation", acceso el 22 de julio de 2016, http://www.cnsnews.com/news/article/michaelw-chapman/pope-francis-join-ecumenical-celebration-protestant-reformation. 
differences between those who are religiously affiliated, on the one hand, and those who are religiously non-affiliated on the other hand. To test this hypothesis, two new 0-1-coded dummy variables were computed, one for Protestant and Catholic respondents and one for Protestant, Catholic and Orthodox vignette persons. Thereafter, these two variables replaced the dummies, capturing the respective influence of the two and three Christian religions on both the respondent and vignette levels. If the in-group/out-group assumption is correct, then the cross-level interaction effect between Christian respondents and Christian vignette persons should become significant. And empirically, this is indeed the case (Table A2, Appendix); Christians have somewhat more trust in other Christians than in people without a religion ( $b=0.144, p<0.05$ tested one-tailed).

In-group favouritism may not only be caused by symbolic threat perceptions but also by realistic threat perceptions. For Bilbao, none of the two cross-level interaction effects between the level of education of the truster (respondent) and the socio-economic status of the vignette person as trustee is significant $(b=0.177$ for secondary education, $\mathrm{b}=-0.059$ for tertiary education). In Cologne, we find a curvilinear pattern; while the cross-level interaction effect between secondary education and unemployment becomes significant $(b=-0.583)$, the crosslevel interaction effect between tertiary education and unemployment does not $(b=-0.233)$. Hence, hypothesis H5a is not confirmed by the data. Finally, we tested for a cross-level interaction between a respondent's gender and the gender of the vignette person (H6a). The effect became significant neither for Bilbao $(b=-0.033)$ nor for Cologne $(b=0.054)$. In light of the higher crime rates of males, this result is very plausible.

\section{Conclusions}

In this contribution, we analysed the impact of different determinants on social trust by using a factorial survey as an experimental design. The main results for conflict theory are rather mixed; empirically, it is confirmed that Catholics, being members of the main religion in Spain, are most trusted, whereas Muslims, as members of the religion most distinct from the other Christian religions, are least trusted. Protestants and people belonging to no religion fall between these two. In Cologne, as a historically Catholic town with a high percentage of citizens belonging to no religion or to the Protestant Church, trust in Catholics, Protestants and Orthodox does not differ significantly. Muslims and 
people without religion are significantly less trusted. The observed difference between Bilbao and Cologne regarding trust in Muslims might be traced back to the fact that Muslims in Germany are mainly from Turkey, which, compared to other Muslim countries, is less traditional and more secularised. This may contribute to reducing the perceived differences between Muslims and other religions in Germany. So far, these results agree well with conflict theory. If in-group/out-group-based threat perceptions should strengthen in-group favouritism, then particularised trust, as measured by cross-level interaction effects between the religion of trusters and trustees who belong to the same ingroup religion, should become significant. This only applies to Cologne after the distinction between the three Christian denominations is removed from the multilevel model. Whether particularised trust is much stronger amongst members of small minority religions, however, cannot be answered by this study, since the number of respondents belonging to these religions (eight Muslims, two Orthodox) is simply too small to be analysed.

Our results concerning language skills clearly confirm conflict theory. Contrary to Huntington, however, language skills in Cologne have a much bigger impact on trust than does religion $(b=-0.328$ vs. a maximal difference of -0.219 between Catholics and Muslims). The analyses also show mixed results for ethnicity; whereas the skin colour of the fictitious vignette person has the expected effect on trust in Bilbao, the impact of this predictor is virtually zero in Cologne. The latter result might be traced back to learning processes from German history, where Jewish people were persecuted and murdered by the national socialists for being members of a different ethnicity.

Contrary to Huntington's macro-theoretical approach, socio-economic factors turned out to be much more powerful predictors for trust than cultural factors. Unemployment had twice the impact on trust in Cologne compared to Bilbao. This difference in trust might be partially explained by the fact that the unemployment rate was much lower in Germany than in Spain; in the first quarter of 2014, unemployment was 5.4 per cent in Germany compared to 25.9 per cent in Spain ${ }^{64}$. Hence, being unemployed was much less likely in Germany than in Spain. Therefore, being unemployed might be perceived in Germany much more than in Spain as the result of low achievement or low motivation or as personal failure, which reduced trust in people who were unemployed.

${ }^{64}$ Eurostat. "Gini Coefficient of Equivalised Disponible Income" - EU-SILC Survey, acceso el 16 diciembro de, 2016, http://appsso.eurostat.ec.europa.eu/nui/show. do?dataset=ilc_di12\&lang=en. 
All in all, for two contexts (towns) with different religious and socioeconomic compositions, we were able to show that socio-economic factors (realistic threat perceptions) are much stronger predictors of social trust than cultural ones (symbolic threat perceptions). Hence, we do not find micro-level support for Huntington's cultural clash thesis. A question which remains unanswered by our study is whether the same pattern of threat perceptions can also be found for situations where no economic resources (money, a mobile phone) are involved; perhaps if the main focus of the topic were more on cultural issues, cultural threat perceptions might be higher than economic ones. Whether or not this is the case is a question to be addressed by future research.

These results represent an evidence that social sustainability as a goal to achieve still requires a long way in Europe, as there are still clear obstacles for the consolidation of a culture of social trust in a context of diversity. This article shows how some characteristics of outgroups are still clearly a burden for the generation of social trust. Similarly, European societies still require a transformation in their attitudes, through education and generational replacement, to fully incorporate diversity and generate the required levels of social trust that contribute to generate a more inclusive European identity. 


\section{Appendix Table A1}

Multilevel Analysis of Level of Trust: Cross-Level Interaction Model for Cologne

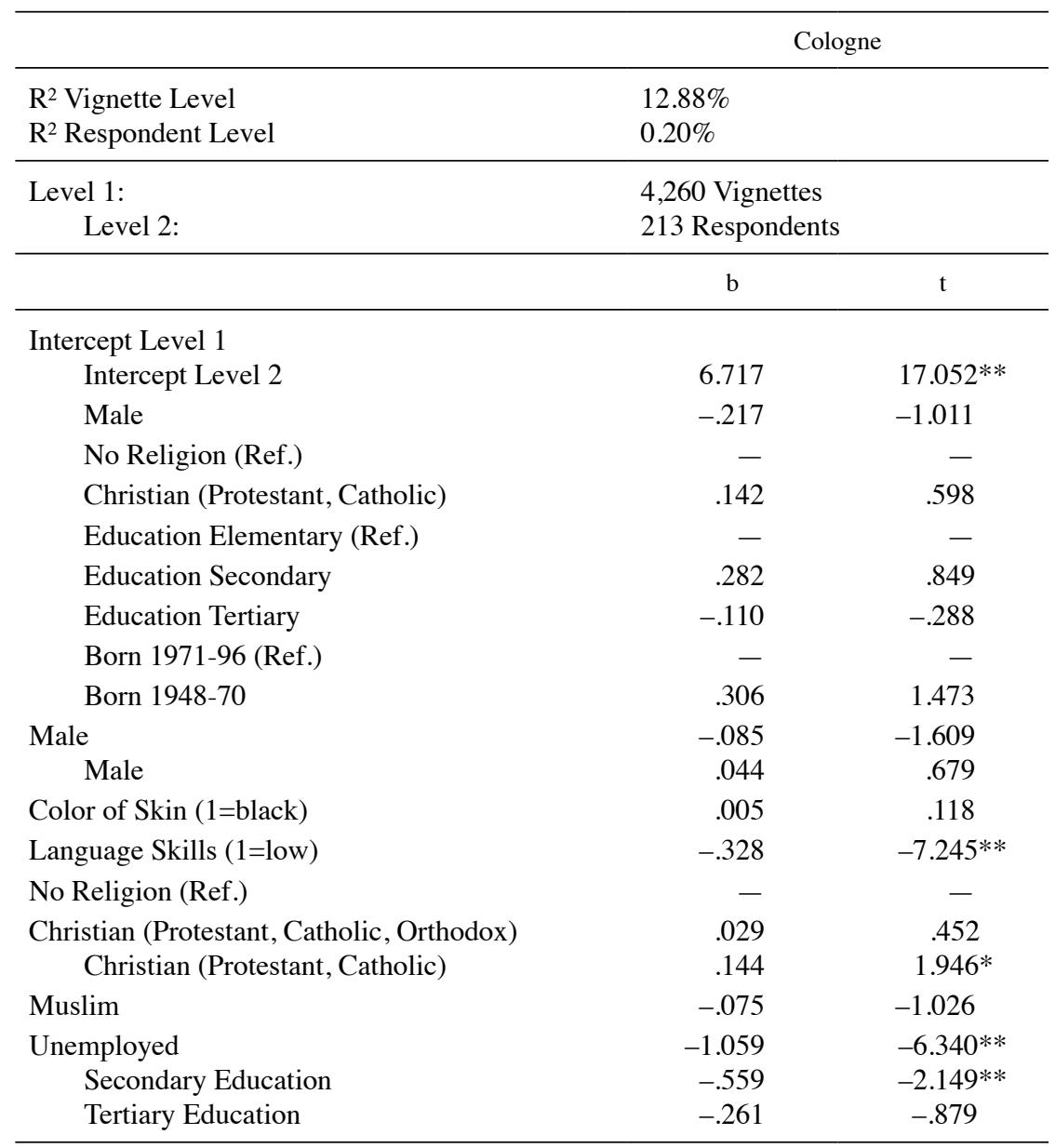

Notes: $* \mathrm{p} \leq 0.05 ; * * \mathrm{p} \leq 0.01$ (tested one-tailed)

1) Only the slopes for the vignette characteristics "Male", and "Christian" turned out to be insignificant and have been fixed for this reason. The intercept and all other slopes were estimated with a significant random component.

For further nots, cf. Table 3 


\section{About the authors}

Dr. Edurne Bartolomé Peral is lecturer and researcher at the University of Deusto, Faculty of Social and Human Sciences, department of International Relations and Humanities. She has been dedicating most part of her research and publications to the study of political culture, political values and attitudes in comparative perspective, political support and trust, and the application of experimental models. She is Program Director for Spain of the European Values Study. Among her most recent publications we can highlight the article Voicu, B. Bartolomé Peral E. et al "How Covid-19 shaped orientations towards solidarity. The cases of Spain, Hungary, and Romania”. Volume 23, 2021 - Issue sup1 in European Societies S887-S904. Moreover, she has published in journals such as Democratization, Journal on Ethnopolitics and Minority Issues in Europe (JEMIE), Methodology-European Journal of Research Methods for the Behavioural and Social Sciences, Migraciones, European societies among others, and she has also published book chapters in Brill, Palgrave McMillan, Routledge and CIS among others.

Dr. Hermann Dülmer is assistant professor (Private Lecturer) of Sociology at the Institute of Sociology and Social Psychology of the University of Cologne, Germany. His methodological interests focus on factorial surveys and on multilevel analysis including multilevel structural equation modeling. His substantive interests include comparative value research and electoral research with a particular emphasis on right-wing extremism. Since many years he is lecturer for workshops on multilevel analysis for GESIS in Mannheim/Germany. He also gave courses on multilevel analysis (including multilevel structural equation modeling) for summer schools at the LCSR of the HSE University in Moscow and St. Petersburg/Russian Federation and at the Institute of Social Sciences of the University of Lisbon/Portugal. He has published in international journals such as Sociological Methods \& Research, Journal of CrossCultural Psychology, Social Justice Research, and the European Journal of Political Research. Among his most recently published articles are Davidov, E., H. Dülmer, J. Cieciuch, A. Kuntz, D. Seddig, and P. Schmidt. 2018. "Explaining Measurement Nonequivalance Using Multilevel Structural Equation Modeling: The Case of Attitudes Toward Citizenship Rights”, Sociological Methods \& Research, 47 (4): 729-60 and Dülmer, H. 2016. "The Factorial Survey: Design Selection and its Impact on Reliability and Internal Validity", Sociological Methods \& Research, 45 (2): 304-47. Together with M. Voicu and I. C. Mochmann he published in 2016 the editor's book Values, Economic Crisis and Democracy, Routledge. 
Dr. Lluís Coromina is is an associate professor at the Faculty of Economics, University of Girona (Spain), he belongs to the area of quantitative methods in social sciences. His research focuses on survey methodology, structural equation models for comparative purposes in sociology, political sciences and social sciences as a broader field. His recent research covers the quality of survey data measurement. He is a reviewer for various international impact factor journals and has published in international journals such as Social Indicators Research, Social Networks, Tourism Management, International Journal of Public Opinion Research, etc. His recent publications are: Bartolomé-Peral, E., y Coromina, L.. 2021. "Attitudes towards Life and Death in Europe: A Comparative Analysis", Czech Sociological Review, 56 (6): 835-62; Coromina, L., y Bartolomé Peral, E.. 2020. "Comparing Alignment and Multiple Group CFA for Analysing Political Trust in Europe during the Crisis", Methodology, 16 (1): 21-40.

\section{Sobre los autores}

Dr. Edurne Bartolomé Peral es profesora doctora encargada en la Universidad de Deusto, Facultad de Ciencias Sociales y Humanas, en el departamento de Relaciones internacionales y Humanidades. Su trabajo se centra en el estudio de la cultura política, valores y actitudes políticas en perspectiva comparada; apoyo político y confianza; y la aplicación de modelos experimentales, ámbitos en los que ha desarrollado la mayor parte de su investigación y publicaciones. Es Program Director para España del European Values Study. Entre sus últimas publicaciones está el artículo Voicu, B. Bartolomé Peral E. et al How Covid-19 shaped orientations towards solidarity. The cases of Spain, Hungary, and Romania. Volume 23, 2021 - Issue sup1 en European Societies S887-S904. Ha publicado en revistas como Democratization, Journal on Ethnopolitics and Minority Issues in Europe (JEMIE), Methodology-European Journal of Research Methods for the Behavioural and Social Sciences, Migraciones, European societies entre otras, y tiene capítulos de libro en editoriales como Brill, Palgrave McMillan, Routledge y CIS entre otras.

Dr. Hermann Dülmer es profesor asistente (private lecturer) de Sociología en el Instituto de Sociología y Psicología social de la Universidad de Colonia, Alemania. Sus intereses metodológicos se centran en las encuestas factoriales y en los análisis multinivel incluyendo modelos de ecuaciones estructurales. Sus intereses sustantivos incluyen la investigación comparativa de los valores y la investigación electoral con un énfasis particular 
en los extremismos de derechas. Desde hace muchos años es profesor de talleres de análisis multinivel para GESIS en Mannheim, Alemania. También ha impartido cursos de análisis multinivel (incluidos modelos de ecuaciones estructurales) para las escuelas de verano en el LCSR de HSE University en Moscú y San Petersburgo, Federación Rusa, y en el Instituto de Ciencias Sociales de la Universidad de Lisboa, Portugal. Ha publicado en revistas internacionales como Sociological Methods \& Research, Journal of Cross-Cultural Psychology, Social Justice Research, y European Journal of Political Research. Entre sus artículos más recientes está Davidov, E., H. Dülmer, J. Cieciuch, A. Kuntz, D. Seddig, y P. Schmidt. 2018. "Explaining Measurement Nonequivalance Using Multilevel Structural Equation Modeling: The Case of Attitudes Toward Citizenship Rights", Sociological Methods \& Research, 47 (4): 729-60 y Dülmer, H. 2016. "The Factorial Survey: Design Selection and its Impact on Reliability and Internal Validity”, Sociological Methods \& Research, 45 (2): 304-47. Junto con M. Voicu y I. C. Mochmann ha publicado en 2016 como editor el libro Values, Economic Crisis and Democracy, en Routledge.

El Dr. Lluís Coromina es profesor titular de universidad en la Facultad de Economía de la Universidad de Girona (España), pertenece al área de métodos cuantitativos en ciencias sociales. Su investigación se centra en la metodología de encuestas, modelos de ecuaciones estructurales con fines comparativos en sociología, ciencia política y ciencias sociales como ámbito más amplio. Su investigación reciente cubre la calidad de la medición de datos de encuestas. Es revisor de diversas revistas internacionales con factor de impacto y ha publicado en revistas internacionales como Social Indicators Research, Social Networks, Tourism Management, International Journal of Public Opinion Research, etc. Sus publicaciones recientes son: Bartolomé-Peral, E, y Coromina, L.. 2021. "Attitudes towards Life and Death in Europe: A Comparative Analysis", Czech Sociological Review, 56 (6): 835-62; Coromina, L., y Bartolomé Peral, E.. 2020. "Comparing Alignment and Multiple Group CFA for Analysing Political Trust in Europe during the Crisis", Methodology, 16 (1): 21-40. 


\section{Derechos de autor}

Los derechos de autor (para la distribución, comunicación pública, reproducción e inclusión en bases de datos de indexación y repositorios institucionales) de esta publicación (Cuadernos Europeos de Deusto, CED) pertenecen a la editorial Universidad de Deusto. El acceso al contenido digital de cualquier número de Cuadernos Europeos de Deusto es gratuito inmediatamente después de su publicación. Los trabajos podrán leerse, descargarse, copiar y difundir en cualquier medio sin fines comerciales y según lo previsto por la ley; sin la previa autorización de la Editorial (Universidad de Deusto) o el autor. Así mismo, los trabajos editados en CED pueden ser publicados con posterioridad en otros medios o revistas, siempre que el autor indique con claridad y en la primera nota a pie de página que el trabajo se publicó por primera vez en CED, con indicación del número, año, páginas y DOI (si procede). Cualquier otro uso de su contenido en cualquier medio o formato, ahora conocido o desarrollado en el futuro, requiere el permiso previo por escrito del titular de los derechos de autor.

\section{Copyright}

Copyright (for distribution, public communication, reproduction and inclusion in indexation databases and institutional repositories) of this publication (Cuadernos Europeos de Deusto, CED) belongs to the publisher University of Deusto. Access to the digital content of any Issue of Cuadernos Europeos de Deusto is free upon its publication. The content can be read, downloaded, copied, and distributed freely in any medium only for non-commercial purposes and in accordance with any applicable copyright legislation, without prior permission from the copyright holder (University of Deusto) or the author. Thus, the content of CED can be subsequently published in other media or journals, as long as the author clearly indicates in the first footnote that the work was published in CED for the first time, indicating the Issue number, year, pages, and DOI (if applicable). Any other use of its content in any medium or format, now known or developed in the future, requires prior written permission of the copyright holder. 